\title{
NEW BRYOPHYTE RECORDS FOR KOSOVO FROM SHARRI NATIONAL PARK
}

\author{
Zenel KRASNiQI ${ }^{1} \&$ Jani Marka ${ }^{2 *}$ \\ ${ }^{1}$ Faculty of Education, 'Hasan Prishtina' University, Rr. "Agim Ramadani", \\ p.n. 10.000, Pristina, Kosovo \\ ${ }^{2}$ Department of Biology, Faculty of Natural Sciences, University of Tirana, Blvd. \\ Zog I, Tirana, Albania
}

\begin{abstract}
Krasniqi, Z. \& Marka, J.: New bryophyte records for Kosovo from Sharri National Park. Nat. Croat., Vol. 30, No. 1, 13-25, 2021, Zagreb.

The bryoflora of Kosovo is poorly investigated. The aim of this study was to increase that knowledge by investigating Sharri National Park for its moss flora. Several field trips were carried out in 2014, 2015 and 2018. About 1900 specimens were collected in various locations of the Park (e.g. Brezovicë, Prevallë, Prroi i Duhlës, Ostrovicë, Restelicë, Mushtishtë, Pashallarë, Burimi i Lumbardhit etc.). Thus far, most of the specimens are identified and represent 159 moss taxa. Seventy-three taxa are new records for Sharri National Park, in which a total of 255 moss taxa have now been reecorded. Furthermore, 19 species are new records for Kosovo, which is now known to have a total of 346 moss taxa. The new records are for Amphidium lapponicum, Blindiadelphus recurvatus, Brachythecium geheebii, Dicranella schreberiana, Didymodon rigidulus, Grimmia dissimulata, G. muehlenbeckii, G. trichophylla, Kiaeria starkei, Paraleucobryum longifolium, Pohlia melanodon, Ptychostomum elegans, Racomitrium affine, R. lanuginosum, R. macounii subsp. alpinum, Rhynchostegium murale, Schistidium dupretii, Thamnobryum alopecurum and Weissia brachycarpa. There is only one species, Brachythecium geheebii, which is a red list species at the European level. In addition, several species, e.g. Grimmia caespiticia, G. reflexidens, Meesia uliginosa, Schistidium papillosum etc. have conservation value in the context of the Balkans. All this shows for the enormous biodiversity values of Sharri National Park and the need for nature conservation through the institution.
\end{abstract}

Key Words: biodiversity, conservation, floristic survey, mosses, the Balkans

Krasniqi, Z. \& Marka, J.: Novi nalazi mahovina s Kosova iz Nacionalnog parka Šar-planina. Nat. Croat., Vol. 30, No. 1, 13-25, 2021, Zagreb.

Flora mahovina Kosova slabo je istražena. Cilj ovog rada je povećati to znanje istraživanjem flore mahovina Nacionalnog parka Šar-planina. Terenska istraživanja odvijala su se tijekom 2014., 2015. i 2018. godine. Prikupljeno je oko 1900 specimens na raličitim lokacijama u Parku (npr. Brezovicë, Prevallë, Prroi i Duhlës, Ostrovicë, Restelicë, Mushtishtë, Pashallarë, Burimi i Lumbardhit itd.). Dosad je određena većina primjeraka, koji predstavljaju 159 svojti mahovina. Od toga su 73 svojte nove za NP Šar-palnina, za koji je sada poznato ukupno 255 svojti mahovina. Osim toga, 19 vrsta su novi nalazi za Kosovo, za koje je sada poznato 346 svojti mahovina. Novi nalazi su Amphidium lapponicum, Blindiadelphus recurvatus, Brachythecium geheebii, Dicranella schreberiana, Didymodon rigidulus, Grimmia dissimulata, G. muehlenbeckii, G. trichophylla, Kiaeria starkei, Paraleucobryum longifolium, Pohlia melanodon, Ptychostomum elegans, Racomitrium affine, R. lanuginosum, R. macounii subsp. alpinum, Rhynchostegium murale, Schistidium dupretii, Thamnobryum alopecurum i Weissia brachycarpa. Jedna je vrsta, Brachythecium geheebii, na Crvenoj listi na europskom nivou. Osim toga je nekoliko vrsta, Grimmia caespiticia, G. reflexidens, Meesia uliginosa, Schistidium papillosum itd., zaštićeno na razini Balkana. Sve to ukazuje na veliku biološku raznolikost NP Šar-planine, i potrebu za institucionalnom zaštitom.

Ključna riječ: biodiverzitet, zaštita, florističko istraživanje, mahovine, Balkan

\footnotetext{
${ }^{*}$ Corresponding author: jani.marka@fshn.edu.al
} 


\section{INTRODUCTION}

The bryophyte flora of Kosovo is poorly known due to the low number of investigations and lack of local bryologists. A checklist of Kosovo bryoflora, based on a literature review, reported 331 taxa, 303 mosses and 28 liverworts (PANTović \& SABOvljEVIĆ, 2017). It is worth mentioning that the above-mentioned figures are based on 13 literature sources and 1068 bryophyte records, which is patently a very low number. In addition, 24 new moss species were recently reported from Germia Regional Park in Pristina district (KRASNIQI \& MARKA, 2018). Therefore, the total number of moss species (327) known for Kosovo is still very low considering the neighboring countries on one hand, and the presence of important mountain massifs (e.g. Bjeshkët e Nemuna/Prokletije and Sharri/Šar Planina), various climates and the diverse geology of bedrocks on the other (SAbovljević et al., 2011; Pantović \& Sabovljević, 2017).

The Sharr Mountains have a remarkable biological diversity (IKMN, 2005; MMPH, 2014; Mustafa et al., 2018). The flora and vegetation are rich in species. Of these species, 86 are deemed of international importance, 26 are listed on the European Red List of Endangered Animals and Plants, and 32 are on the IUCN Red List of Threatened Plants (IUCN, 1990). A part of the Sharr Mountains was declared a National Park in 1986 (IKMN, 2005). According to IUCN the Sharr Mountains are listed on the international list of protected areas (IKMN, 2005).

The Sharr Mountains have been investigated for bryophytes by MARTINČıč (1980) and by SABOvlJević (1998), with 182 taxa reported so far. Overall it should be considered underexplored and further investigations should be encouraged. Therefore, the aim of this study is to increase the knowledge on moss flora in the area of the Sharr Mountains.

\section{MATERIAL AND METHODS}

Several field trips were carried out in the Sharri Mountains in 2014, 2015 by the first author and in 2018 by both authors and ca.1900 specimens of mosses were collected at various sites (Tab. 1, Fig. 1) and on different ecological substrates. Most of the specimen identification was performed jointly by the contributors during visits of the first author to Tirana University. The voucher specimens are stored in the herbarium collection at Faculty of Education, Hasan Prishtina University, in Pristina. The nomenclature of the taxa is based on HodgetTs et al. (2020), floristic elements on Sмiтн (2004) and red-list comments and distribution in the Balkans on HodgetTs \& LOCKHART (2020). The abbreviations used for conservation status are: CR - critically endangered, EN - endangered and VU - vulnerable.

\section{Sharr Mountains}

The protected area of the Sharri Mountains extends over 39,000 ha and lies within the boundaries of four municipalities: Prizren, Shtërpcë, Therandë and Kaçanik (IKMN, 2005). The highest peak is Luboteni peak at $2496 \mathrm{~m}$ above sea level. The Sharri Mountains have natural heritage values according the criteria of the World Heritage Convention (Mustafa et al., 2018).

Geomorphology - The morphological formation of the Sharri Mountains has been influenced by the tectonic movements of the land which have created geomorphologic compressions, as well as external forces which have had an impact on glaciers, 
water courses etc. As a result of the glacial action, depths have been created which have later been transformed into glacial lakes such as Meadow Lake, Jazhinca Lake and other very attractive lakes which are popularly known as the "Eyes of the Mountains". Various rock types took part in the geological formation of Sharr Mountains during the Paleozoic period, e.g. limestone rocks, silicate, marble etc. (IKMN, 2005; MMPH/AMMK, 2013; MMPH, 2014). The Sharr Mountains contain eight features related to glacial relief and three additional features related to pre-glacial relief (Mustafa et al., 2018).

Climate - The area has a continental climate characterized by long winters, with heavy snowfall and cool summers. The average annual temperature for the Sharri Mountains at two meteorological stations (the North Macedonia and the Kosovo side) is $8.4^{\circ} \mathrm{C}$; with January being the coldest month at 1.8 and $-1.3{ }^{\circ} \mathrm{C}$ for the two stations, respectively. The annual relative air humidity is about $67-70 \%$ for both stations with average rainfalls from 670 to $1200 \mathrm{~mm}$. Wind velocities range from 1 to $16 \mathrm{~m} / \mathrm{s}$, with the south, southwest and southeast winds dominating (IKMN, 2005; MMPH/AMMK, 2013; MMPH, 2014).

Hydrology - As a result of frequent rainfall, the Sharr Mountains region is extremely rich in waters that encompass a large number of lakes of glacial origin, springs and streams of several rivers. There are outflows of two rivers in the territory of the Sharr Mountains - the Lepenci and the Lumbardhi of Prizren. The Lepenci is formed by the confluence of water courses emanating from the mountains of Cerevc and Jezerc and in its course it receives water from numerous tributaries. Prizren's Lumbardhi rises in the Prevalla region, on the slopes of Mount Bistrica, which also collects many water courses rich in water. It has a length of $31 \mathrm{~km}$ and the catchment area is $266 \mathrm{~km}^{2}$ (PASHA, 1975; LABUs, 1979). There are 25 lakes in the territory of the Sharr Mountains at $1900 \mathrm{~m}$ above sea level, which represent the special natural values of the Sharr Massif (IKMN, 2005; MMPH/AMMK, 2013; MMPH, 2014).

Landscape and vegetation - The Sharr Mountains are distinguished for their alpine scenery and by diverse natural values (ÇAVOLLI \& GASHI, 1979; Mustafa et al., 2018). Attractive landscapes consist of forests, pastures, meadows accompanied with fallen branches, often created by forest cuttings, through which pass rivers and streams, canyon-like places and gorges with waterfalls or lakes, contributing to the pleasant experience to be had in this beautiful natural setting (IKMN, 2005; MMPH/ AMMK, 2013; MMPH, 2014). The Sharr Mountains have a rich flora, with about 2000 plant species and 68 plant associations known thus far - with endemics, relicts and endangered species. Particularly to be mentioned are the forest associations of Pinus heildreichii, P. peuce, P. mugo, Acer heildreichii, Taxus baccata, Rhododendron ferrugineum etc. (IKMN, 2005). Furthermore, 3 endemic or endemic-relict plant associations, are found in the Sharr Mountains (grassland associations: Achilleoalexandri-regis-Onobrychietum scardicae, Sedo-Bornmullerietum dieckii, and Potentillo doerfleri-Juncetum trifidi) (Mustafa et al., 2018).

\section{RESULTS AND DISCUSSION}

In total 159 moss taxa were recorded during our field trips in the Sharr Mountains. In this section only the species which are new for Kosovo are listed and those which have conservation interest in the Balkans. Each species is followed by numbers that correspond to the collection sites. The complete list of the species and their occurrence in the study area is given in the Appendix. 
Tab. 1. List of collection sites and representative coordinates.

\begin{tabular}{|l|l|l|l|l|}
\hline Site & \multicolumn{1}{|c|}{ Name } & \multicolumn{1}{|c|}{ Altitude } & \multicolumn{1}{|c|}{ Coordinates } & \multicolumn{1}{c|}{ Date } \\
\hline 1. & Stanet e Mushtishtit & $1418 \mathrm{~m}$ & $42^{\circ} 15.607^{\prime} \mathrm{N}, 20^{\circ} 54.745^{\prime} \mathrm{E}$ & $09 / 08 / 2014$ \\
\hline 2. & Stanet e Mushtishtit & $1523 \mathrm{~m}$ & $42^{\circ} 15.490^{\prime} \mathrm{N}, 20^{\circ} 55.050^{\prime} \mathrm{E}$ & $09 / 08 / 2014$ \\
\hline 3. & Pashallare & $1746 \mathrm{~m}$ & $42^{\circ} 14.920^{\prime} \mathrm{N}, 20^{\circ} 54.690^{\prime} \mathrm{E}$ & $09 / 08 / 2014$ \\
\hline 4. & Pashallare & $1802 \mathrm{~m}$ & $42^{\circ} 14.640^{\prime} \mathrm{N}, 20^{\circ} 54.900^{\prime} \mathrm{E}$ & $09 / 08 / 2014$ \\
\hline 5. & Pashallare & $2029 \mathrm{~m}$ & $42^{\circ} 14.434^{\prime} \mathrm{N}, 20^{\circ} 54.665^{\prime} \mathrm{E}$ & $09 / 08 / 2014$ \\
\hline 6. & Ostrovicë & $1828 \mathrm{~m}$ & $42^{\circ} 15.323^{\prime} \mathrm{N}, 20^{\circ} 52.554^{\prime} \mathrm{E}$ & $09 / 08 / 2014$ \\
\hline 7. & Restelicë & $1958 \mathrm{~m}$ & $41^{\circ} 55.060^{\prime} \mathrm{N}, 20^{\circ} 38.716^{\prime} \mathrm{E}$ & $01 / 08 / 2015$ \\
\hline 8. & Restelicë & $1851 \mathrm{~m}$ & $41^{\circ} 54.248^{\prime} \mathrm{N}, 20^{\circ} 39.021^{\prime} \mathrm{E}$ & $01 / 08 / 2015$ \\
\hline 9. & Restelicë & $1847 \mathrm{~m}$ & $41^{\circ} 53.820^{\prime} \mathrm{N}, 20^{\circ} 38.731^{\prime} \mathrm{E}$ & $01 / 08 / 2015$ \\
\hline 10. & Restelicë & $1813 \mathrm{~m}$ & $41^{\circ} 53.873^{\prime} \mathrm{N}, 20^{\circ} 38.175^{\prime} \mathrm{E}$ & $01 / 08 / 2015$ \\
\hline 11. & Krushevë - Restelicë & $1250 \mathrm{~m}$ & $41^{\circ} 57.744^{\prime} \mathrm{N}, 20^{\circ} 38.894^{\prime} \mathrm{E}$ & $01 / 08 / 2015$ \\
\hline 12. & Kalaja e Prizrenit & $521 \mathrm{~m}$ & $42^{\circ} 12.522^{\prime} \mathrm{N}, 20^{\circ} 44.734^{\prime} \mathrm{E}$ & $15 / 08 / 2014$ \\
\hline 13. & Prevallë (Gryka e Lumbardhit) & $1585 \mathrm{~m}$ & $42^{\circ} 10.730^{\prime} \mathrm{N}, 20^{\circ} 57.779^{\prime} \mathrm{E}$ & $15 / 08 / 2014 ;$ \\
& & & & $01,02 / 10 / 2018$ \\
\hline 14. & Prevallë (Burimi i Lumbardhit) & $1560 \mathrm{~m}$ & $42^{\circ} 9.968^{\prime} \mathrm{N}, 20^{\circ} 57.440^{\prime} \mathrm{E}$ & $15,18 / 08 / 2014$ \\
\hline 15. & Bistra & $1853 \mathrm{~m}$ & $42^{\circ} 9.156^{\prime} \mathrm{N}, 20^{\circ} 57.485^{\prime} \mathrm{E}$ & $02 / 10 / 2018$ \\
\hline 16. & Prroi i Durlës & $1737 \mathrm{~m}$ & $42^{\circ} 11.012^{\prime} \mathrm{N}, 21^{\circ} 2.175^{\prime} \mathrm{E}$ & $05 / 08 / 2014$, \\
\hline 17. & Brezovica & $1757 \mathrm{~m}$ & $42^{\circ} 10.947^{\prime} \mathrm{N}, 21^{\circ} 2.198^{\prime} \mathrm{E}$ & $05 / 08 / 2014$ \\
\hline
\end{tabular}

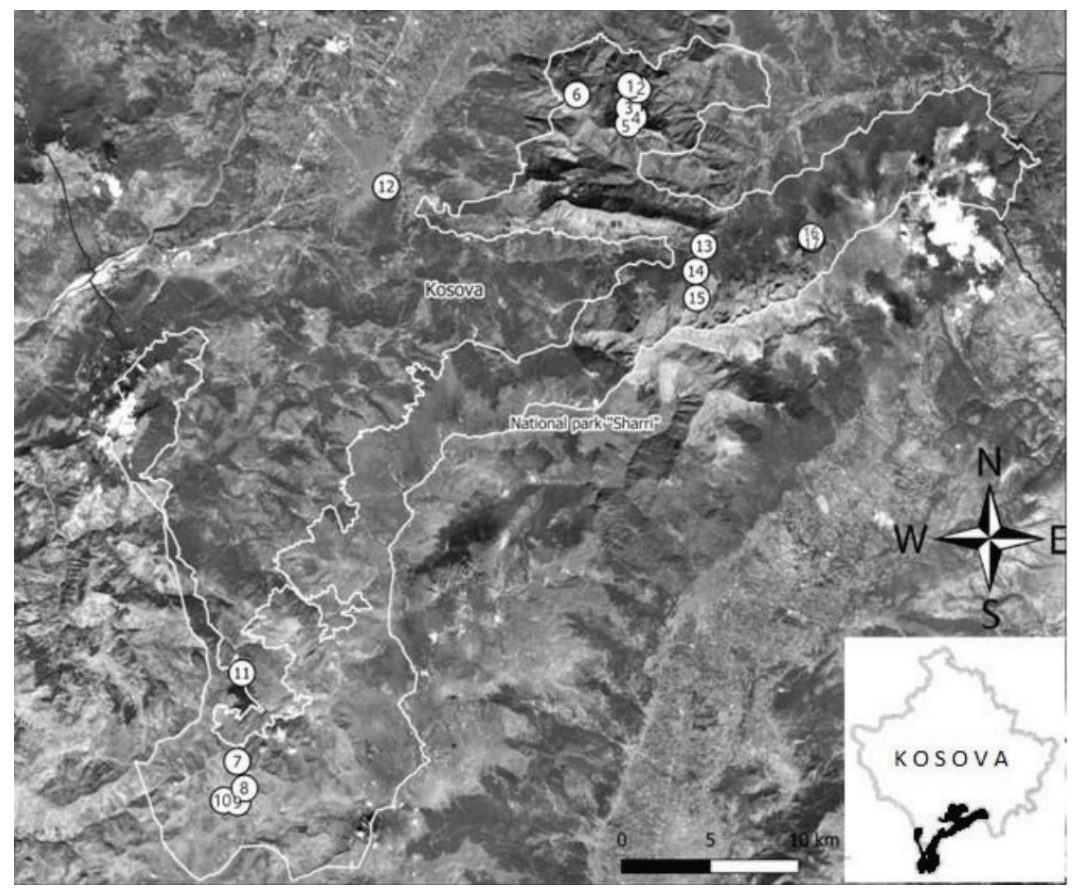

Fig. 1. Sharri Mountains National Park Kosovo; the numbers indicate the localities explored and correspond with numbers in Tab. 1. Adapted from Google Maps 2019. 


\section{New moss species for Kosovo}

Amphidium lapponicum (Hedw.) Schimp. - 13: on basic rock crevices. This Circumpolar Boreo-arctic Montane species is recorded in several countries of Balkan Peninsula, except for Croatia, Greece and Montenegro, mainly in high mountains. It was recently recorded in northern Albania (MARKA et al., 2018) near the border with Montenegro. Its distribution in the Balkans is the southern limit of its distribution in SE Europe, its populations are rare and, therefore, it is red listed for Romania (CR) and Bulgaria (VU), and data deficient for Serbia and Slovenia.

Blindiadelphus recurvatus (Hedw.) Fedosov \& Ignatov - 16: on acidic rock. This European Boreo-temperate species is reported from many Balkan countries, except for North Macedonia and Serbia. It is red listed for Slovenia (EN) and data deficient for Albania.

Brachythecium geheebii Milde - 13, 14, 16: on acidic rocks. This European endemic species is recorded in all countries of the Balkan Peninsula in the high mountains. $B$. geheebii is a European red-list species (VU). In addition, in the Balkans it is red listed for Bulgaria (EN) and Romania (CR), near threatened for Slovenia and data deficient for Albania.

Dicranella schreberiana (Hedw.) Dixon - 13: in basic humid rock. This Circumpolar Boreo-temperate species is recorded in many countries of the Balkan Peninsula, except for Albania and North Macedonia. It is data deficient for Montenegro, Serbia and Slovenia.

Didymodon rigidulus Hedw. $-2,10,11,16$ : on basic rocks, a spring. This Circumpolar Boreo-temperate species is very common and widespread in the Balkans.

Grimmia dissimulata E.Maier - 14, 15, 16: on basic rocks. This species was described in 2002 (MAIER, 2002); its occurrence seems to be very common in the Balkans.

Grimmia muehlenbeckii Schimp. $-7,14,16$ : on acidic rocks. This species, closely related with G. trichophylla, usually occurs in the montane and alpine areas of the Balkans. It is not yet known only from Bosnia \& Herzegovina, it is red-listed for both Bulgaria and Romania (VU) and data deficient for Montenegro and Slovenia.

Grimmia trichophylla Grev. - 12, 14, 16: on siliceous rocks. This Circumpolar Wide-temperate species is present in all countries of Balkan Peninsula, typically in acidic rocks, and red listed for Romania (EN).

Kiaeria starkei (F.Weber \& D.Mohr) I.Hagen - 14: on siliceous rock. This Circumpolar Arctic-montane species is reported from high mountains of several Balkan countries, except for Croatia, Greece, North Macedonia and Serbia. It is red listed for Slovenia (EN) and data deficient for Montenegro.

Paraleucobryum longifolium (Hedw.) Loeske - 16: on acidic rock. This Circum Boreal-montane species is reported from all Balkan countries, it is red listed for Serbia (VU) and data deficient for Albania.

Pohlia melanodon (Brid.) A.J.Shaw - 17: on basic soil. This Circumpolar Southerntemperate species is reported in all Balkan countries and red listed for Slovenia (EN).

Ptychostomum elegans (Nees in Brid.) Holyoak-13, 16: on humid basic rocks. This European Boreal-montane species is recorded in all Balkan countries. It is red-listed for both Bulgaria and Slovenia (VU). 
Racomitrium affine (F.Weber \& D.Mohr) Lindb. - 4, 14, 16: on acidic rocks. This Circumpolar Boreo-temperate element is reported from many Balkan countries, except for Bosnia \& Herzegovina and North Macedonia, apparently much less frequently than R. sudeticum; and red listed for Bulgaria (VU) and data deficient for Montenegro.

Racomitrium lanuginosum (Hedw.) Brid. -14, 15, 16: on acidic rocks. This Circumpolar Boreo-arctic Montane species is reported from several Balkan countries, except for Albania, Croatia and North Macedonia. However, its threat status is not very well known in the Balkans.

Racomitrium macounii subsp. alpinum (E.Lawton) Frisvoll - 14: on acidic rock. This European Boreal-montane element is reported in the Balkans only from Bulgaria and Romania (R. macounii subsp. macounii for both countries, and R. macounii subsp. alpinum doubtfully reported for Bulgaria), and red listed for both countries (respectively VU and CR).

Rhynchostegium murale (Hedw.) Schimp. - 6: on beech cortex. This European-temperate element is reported and common in all Balkan countries.

Schistidium dupretii (Thér.) W.A.Weber - 5, 12, 13, 16: on silicate rocks. This Circumboreal-montane species is recorded from several Balkan countries, except for Bosnia \& Herzegovina and Bulgaria, and it is data deficient for Montenegro.

Thamnobryum alopecurum (Hedw.) Gangulee - 13: on limestone rock in a stream. This European Temperate element is reported and common in all Balkan countries.

Weissia brachycarpa (Nees \& Hornsch.) Jur. - 5: on acidic rock crevices. This Circumpolar Southern-temperate is reported and common in all Balkan countries.

\section{Taxa of conservation interest in the Balkan context}

There are several more taxa, some of them formerly European red list candidates (HodgetTs, 2015), which however do have conservation value in the Balkan context.

Distichium inclinatum (Hedw.) Bruch \& Schimp. - 13: on calcareous rock. This Circumpolar Boreo-arctic Montane element is previously recorded for the Sharri Mountains in two locations (MARTINČIČ, 1980). It is recorded from all Balkan countries and red listed (VU) for Bulgaria.

Grimmia caespiticia (Brid.) Jur. -14, 15, 16: on acidic rocks. This Eurosiberian Boreo-arctic Montane element is a new record from Sharri Mountains, meanwhile for Kosovo it has been previously reported from Bjeshkët e Nemuna (Prokletije) in two different localities, respectively in Mt. Gjeravica (Djeravica) and Bistrica (Lumbardhi i Deçanit) (MARTINČıč, 2006). G. caespiticia is reported from several Balkan countries, except for Bosnia \& Herzegovina, Croatia and Slovenia. It has been recently reported from Albania (MARkA, 2018). It is red listed for Montenegro (VU), Romania (CR) and Serbia (VU).

Grimmia reflexidens Müll. Hal. - 14: on acidic rock. This Subarctic-subalpine element is previously reported only from one locality from the Sharri Mountains (SABOVLJEvić, 1998). It is known from several Balkan countries, excluding Bosnia \& Herzegovina, Croatia and Slovenia, and it is red listed for Romania (EN) and data deficient for Albania and Montenegro. 
Kiaeria starkei - see notes for this species on the previous section of new records for Kosovo.

Lescuraea mutabilis (Brid.) Lindb. ex I.Hagen - 6, 15, 16: on acidic rock, on beech bark. This Circumpolar Boreal-montane element was previously recorded for Sharri Mountains in two locations (MARTINČIČ, 1980) and (SABOVLJEVIĆ, 1998). It is recorded from all Balkan countries and red listed (VU) for both Bulgaria and Romania.

Lescuraea radicosa (Mitt.) Mönk. - 6, 12, 14: on acidic rock, on beech bark. This species has previously been recorded for Sharri Mountains in two locations (MARTINČIČ, 1980; SABOVLJEVIĆ, 1998). It is recorded from many Balkan countries, but not for Bosnia \& Herzegovina and Croatia, and is near threatened for Bulgaria and Romania.

Lescuraea saxicola (Schimp.) Molendo - 6: on rock. This Circumpolar Boreal-montane element is recorded for the first time for the Sharri Mountains. It is recorded from many Balkan countries, but not for Bosnia \& Herzegovina and Croatia, and is red listed (VU) for Bulgaria, Romania and Slovenia.

Meesia uliginosa Hedw. - 14: on calcareous rock. This Circumpolar Boreo-arctic Montane element is previously recorded for Sharri Mountains in two different localities (MARTINČIČ, 1980). It is known from many Balkan countries, but not for Albania and Serbia, and it is red listed for both Bulgaria and Montenegro (VU).

Oligotrichum hercynicum (Hedw.) Lam. \& DC. - 14, 15, 16: on acidic soil. This Circumpolar Boreo-arctic Montane element was previously recorded for Sharri Mountains in one locality (MARTINČIČ, 1980). It is recorded from several Balkan countries, but not for Albania, Croatia, Greece and Montenegro, and is red listed (VU) for Serbia.

Palustriella decipiens (De Not.) Ochyra - 2, 3, 4, 7, 16: on silicate rocks near the stream. This European Boreo-arctic Montane element is previously recorded for Sharri Mountains in two localities (MARTINČIČ, 1980; SABOvljEviĆ, 1998). It is recorded from many Balkan countries, but not for Croatia, and is red listed (VU) for Bulgaria. However, $P$. decipiens and the next two following species are threatened, since as wetland species their habitats are very threatened in the Balkans by climate change.

Philonotis seriata Mitt. - 7, 8, 9, 10, 14, 15, 16: on wet acidic rocks. This Eurosiberian Boreo-arctic Montane element has previously been recorded for the Sharri Mountains (RANĐELović et al., 1998). It is recorded from Balkan countries, except for Croatia, and is red listed (EN) for Slovenia.

Rhizomnium pseudopunctatum (Bruch \& Schimp.) T.J.Kop. - 14, 16: on wet rock. This Circumpolar Boreal-montane element has previously been recorded for the Sharri Mountains (SABovljEvić, 1998). It is recorded from many Balkan countries, though not for Croatia and Greece, and data deficient for Bulgaria.

Schistidium papillosum Culm. - 14: on acidic rock. This Circumpolar Boreo-arctic Montane element was previously recorded for Sharri Mountains in one locality (MARTINČIČ, 1980). It is recorded from many Balkan countries, but not for for Bosnia \& Herzegovina and Croatia, and is data deficient for Albania, Bulgaria, Montenegro and Slovenia.

Sciuro-hypnum starkei (Brid.) Ignatov \& Huttunen - 14, 16: on basic rock. This Circumpolar Boreal-montane element has now been recorded for the first time for the Sharri Mountains. It is recorded from all Balkan countries and is red listed (VU) for Bulgaria, near threatened for Romania and data deficient for Montenegro. 
Timmia norvegica J.E.Zetterst. - 13: on limestone rock. This Circumpolar Boreo-arctic Montane element has been recorded now for the first time for Sharri Mountains. It is recorded from Albania, Bulgaria, Bosnia \& Herzegovina and Romania, and it is red listed (CR) for Bulgaria and (VU) for Romania.

\section{CONCLUSIONS}

Of the 159 species found in the Sharr Mountains, 73 species are reported for the first time for the range. And 19 of them are reported as new for Kosovo. Hence, with this study the number of moss species in the Sharr National Park rises to 255 and the number of moss species in Kosovo to 346. There is only one species, Brachythecium geheebii, which is a red list species (VU) at the European level. In addition, several species, e.g. Grimmia caespiticia, G. Reflexidens, Lescuraea mutabilis, L. Saxicola, Meesia uliginosa, Oligotrichum hercynicum, Palustriella decipiens, Schistidium papillosum, Timmia norvegica etc. Have conservation value in the context of the Balkans. All this shows the enormous biodiversity values of Sharri National Park and the need for nature conservation by institutions and authorities.

\section{ACKNOWLEDGMENTS}

The authors are grateful to Mr. Xhavit Malaj, from the Directorate of Sharr National Park, for being a field guide during all the field trips. The first author is grateful to the Department of Biology (Faculty of Natural Sciences, University of Tirana) for permission to use facilities and labs during research visits. Finally, the authors are also grateful to the anonymous reviewers for their valuable suggestions on improving the manuscript.

Received March 24, 2020

\section{REFERENCES}

Çavolli, R. \& Gashi, M., 1979: Këshillimi mbi parqet nacionale dhe regjionale të Jugosllavisë. Brezovicë, KSA e Kosovës.

Hodgetts, N., 2015: Checklist and country status of European bryophytes - towards a new Red List for Europe. Irish Wildlife Manuals, No. 84. National Parks and Wildlife Service, Department of Arts, Heritage and the Gaeltacht, Ireland

Hodgetts, N. \& Lochart, N., 2020: Checklist and country status of European bryophytes - update 2020. Irish Wildlife Manuals, No. 123. National Parks and Wildlife Service, Department of Culture, Heritage and the Gaeltacht, Ireland.

Hodgetts, N.G., Söderström, L., Blockeel, T.L., Caspari, S., Ignatov, M.S., Konstantinova, N.A., Lockhart, N., Papp, B., Schröck, C., Sim-Sim, M., Bell, D., Bell, N.E., Blom, H.H., BruggemanNannenga, M.A., Brugués, M., Enroth, J., Flatberg, K.I., Garilleti, R., Hedenäs, L., Holyoak, D.T., Hugonnot, V., Kariyawasam, I., Köckinger, H., Kučera, J., Lara, F. \& Porley, R.D.,2020: An annotated checklist of bryophytes of Europe, Macaronesia and Cyprus. Journal of Bryology 42(1), 1-116. DOI: 10.1080/03736687.2019.1694329

IKMN, 2005: Vlerat e trashegimise natyrore të Kosoves. Instituti i Kosovës për mbrojtjen e natyrës,Prishtinë. Retrieved October 20, 2019 from https://www.ammk-rks.net/repository/ docs/Vlerat_e_trashegimis_natyrore_te_Kosoves.pdf

IUCN, 1990:United Nations List of National Parks and Protected Areas. IUCN, Gland, Switzerland and Cambridge, UK. 
KraSNiQI, Z. \& MARKa, J., 2018: Të dhëna paraprake për florën e myshqeve të Parkut Rajonal të Gërmisë (Kosovë). Buletini Shkencor i Fakultetit të Shkencave të Natyrës 26, 98-108.

Labus, D., 1979: Bilanci ujor i pellgut të lumit Drini i Bardhë. Kërkime Gjeografike, Prishtinë: 107-123.

Maier, E., 2002: The genus Grimmia (Musci, Grimmiaceae) in the Himalaya. Candollea 57, 143-238.

Marka, J., Blockeel, T.L., Long, D.G. \& PAPp, B., 2018: Bryophytes new to Albania from the British Bryological Society field meeting in 2014. Journal of Bryology 40, 163-172.

MARTinčıč, A., 1980: Prispevek k poznavanju mahovne flore Jugoslavije II - Šar planina. Biološki vestnik 28, 87-102.

Martinčıč, A., 2006: Moss flora of the Prokletije Mountains (Serbia and Montenegro). Hacquetia 5, 113-130.

MMPH/AMMK, 2013: Parku Kombëtar "Sharr", Plani Hapsinor, Instituti për Planifikim Hapësinor. Prishtinë. Retrieved May 21, 2021 from http://www.ammk-rks.net/repository/docs/PHPK_ Sharri_shq.pdf

MMPH, 2014: Parku Kombëtar Sharri: Plani i menaxhimit.Ministria e Ambientit dhe PlanifikimitHapsinor, Prishtinë. Retrieved February 15, 2020 from https:/ / mmph.rks-gov.net/assets/cms / uploads/files/Publikimet/Plani_i_menaxhimit_i_PK_Sharri_verzioi_shqipe_342423.pdf.

Mustafa, B., Hajdari, A., Mustafa, V. \& Pulaj, B., 2018: Natural Heritage in the Republic of Kosovo: Looking for Potential UNESCO Sites. Landscape Online 63, 1-16, DOI 10.3097/LO.201863

Pantović, J. \& Sabovljević, M., 2017: Bryophytes of Kosovo. Phytotaxa 306 (2), 101-123

Pasha, H., 1975. Natyra e Kosovës, Vetitë Fiziko Gjeografike të Ujëmbledhësit të Drinit të Bardhë. Pristina, Kosovo.

RanĐelović, V., Zlatković, B. \& Amidžıć, L., 1998: Flora i vegetacija visokoplaninskih tresava Šar planine. Zaštita prirode 50, 377-387.

SAbovljević, M., 1998: The rare Bryophytes of Šara Mountain, Yugoslavia. Planta Europa 2, $152-161$.

Sabovljević, M., Alegro, A., Sabovljević, A., Marka, J. \& Vujičıć, M., 2011: An insight into diversity of the Balkan Peninsula Bryophyte flora in the European background. Revue d ecologie-la terre et la vie 66, 399-413.

Sмiтh, A.J.E., 2004: The moss flora of Britain and Ireland. 2nd ed. Cambridge University Press, Cambridge.

\section{APPENDIX 1.}

Full list of 159 taxa recorded. Given for each species is the distribution in the study area and the substrate. Furthermore, symbols indicate the following: ${ }^{*}$ - new reports for Kosovo, ${ }^{* *}-$ new records for Sharri.

Abietinella abietina (Hedw.) Fleisch. - 12, 13, 16: on soil and basic rocks.

*Amphidium lapponicum (Hedw.) Schimp. - 13: on basic rock crevices.

**Amphidium mougeotii Bruch \& Schimp. - 14: on acidic rock.

Andreaea rupestris Hedw. - 14: on siliceousrock.

**Antitrichia curtipendula Timm ex Hedw.) Brid. - 13: on basic rock.

**Atrichum undulatum (Hedw.) P. Beauv. - 10, 13, 16: on wet basic rocks and wet soil.

**Barbula unguiculata Hedw. - 7: on limestone rock.

Bartramia halleriana Hedw. - 13, 16: on wet rock, on basic rock.

Bartramia ithyphylla Brid. - 15, 16: on shaded basic rocks.

Bartramia pomiformis Hedw. $-7,8,9,10,11$ : on acidic rocks.

**Blindia acuta (Hedw.) Bruch \& Schimp. - 13, 14, 15: on wet basic rocks.

*Blindiadelphus recurvatus (Hedw.) Fedosov \& Ignatov. - 16: on acidic rock. 
Brachytheciastrum velutinum (Hedw.) Schimp. - 3, 4, 5, 6, 13, 14, 15, 16: on soil, stone and basic rocks, beech bark.

**Brachythecium albicans (Hedw.) Schimp. - 3, 4, 5, 13, 14, 15: on soil, on silicate rocks. *Brachythecium geheebii Milde - 13, 14, 16: on acidic rocks.

Brachythecium glareosum (Spruce) Schimp. - 3, 4, 5, 8, 9, 10, 11, 13, 16: on soil and basic rocks.

Brachythecium mildeanum (Schimp.) Schimp. - 16: on basic rock in stream.

Brachythecium rivulare Schimp. - 7, 8, 9, 10, 11, 13, 14, 15, 16: on wet basic rocks alongside streams.

**Brachythecium rutabulum (Hedw.) Schimp. - 5, 13, 16: on rocks alongside streams and wet basic rocks.

**Brachythecium salebrosum (Hoffm. ex F.Weber\& Mohr) - 16, 17: on rocks.

**Brachythecium tommasinii (Sendtn. ex Boulay) Ignatov \& Huttunen - 1, 2, 13, 14, 15, 16, 17: on soil and rocks.

Calliergonella cuspidata (Hedw.) Loeske - 7, 8, 9, 10, 11, 13, 14, 15: on stream and wet rocks.

Campylium protensum (Brid.) Kindb. - 15, 16: wet limestone rock, near and on the stream.

Campylium stellatum (Hedw.) Lange \& C.E.O. Jensen - 13, 14, 15, 16: wet rock, near streams, on soil.

**Campylophyllopsis calcarea (Crundw. \& Nyholm) Hedenäs - 16: on limestone rock. Campylophyllum halleri (Hedw.) M.Fleisch. - 9: on wet basic rock near stream.

Ceratodon purpureus (Hedw.) Brid. $-7,8,11,14,16$ : on soil, on acidic rocks.

Cirriphyllum crassinervium (Taylor) Loeske \&M.Fleisch. -16: on basic rock.

**Cirriphyllum piliferum (Hedw.) Grout - 14, 15, 16: on wet rock, on basic rock.

Climacium dendroides (Hedw.) F.Weber\& D.Mohr. - 14, 15, 16: on poor soil, on wet basic rock.

Cratoneuron filicinum (Hedw.) Spruce - 3, 4, 5, 13, 14, 16: on wet basic rocks.

**Dichodontium pellucidum (Hedw.) Schimp. - 6, 7, 14, 16: on wet rock, on basic rock.

*Dicranella schreberiana (Hedw.) Dixon - 13: in basic humid rock.

Dicranum scoparium Hedw. - 1, 2, 3, 4, 5, 12, 13, 14, 15, 16: on rock, on silicate rock.

**Dicranum tauricum Sapjegin - 16: on pine bark.

**Didymodon acutus (Brid.) K.Saito - 16: basic rock.

**Didymodon luridus Hornsch - 14: on calcareous rock.

*Didymodon rigidulus Hedw. - 2, 10, 11, 16: on basic rocks, fountain.

**Didymodon vinealis, (Brid.) R.H.Zander - 14: on basic rock.

Distichium capillaceum (Hedw.) Bruch \& Schimp. - 7, 13: on calcareous rock.

Distichium inclinatum (Hedw.) Bruch \& Schimp. - 13: on calcareous rock.

Encalypta streptocarpa Hedw. - 13: on calcareous rock.

Encalypta vulgaris Hedw. - 12: on calcareous rock.

**Eurhynchiastrum diversifolium (Schimp.) J. Guerra- 7, 16: on calcareous rock.

${ }^{* * E u r h y n c h i a s t r u m ~ p u l c h e l l u m ~(H e d w .) ~ I g n a t o v ~ \& ~ H u t t u n e n ~-~ 16: ~ o n ~ r o c k . ~}$

**Fissidens taxifolius Hedw. - 14: on rock crevices.

**Flexitrichum gracile (Mitt.) Ignatov \&Fedoso - 8, 9, 14, 16: on rock. 
**Funaria hygrometrica Hedw. - 5: on rock.

**Grimmia alpestris (F.Weber \& D.Mohr) Schleich. - 5, 16: on acidic rock.

**Grimmia caespiticia (Brid.) Jur. - 14, 15, 16: on siliceousrock.

*Grimmia dissimulata E. Maier - 14, 15, 16: on basic rocks.

**Grimmia hartmanii Schimp. - 1, 2, 3, 4, 5, 12, 13, 14, 15, 16, 17: on rocks and stones.

**Grimmia montana Bruch \& Schimp. - 14, 16: on acidic rock.

*Grimmia muehlenbeckii Schimp. - 7, 14, 16: on acidic rocks.

**Grimmia ovalis (Hedw.) Lindb. $-3,4,5,6,13,14,15,16$ : on acidic rocks.

**Grimmia pulvinata (Hedw.) Sm. - 16: on basic rock.

Grimmia ramondii (Lam. \& DC.) Margad - 14, 15, 16: on acidic rock.

Grimmia reflexidens Müll. Hal. - 14: onacidic rock.

*Grimmia trichophylla Grev. - 12, 14, 16: on siliceous rocks.

**Gymnostomum calcareum Nees \& Hornsch. - 14: on wet soil, on calcareous rock.

**Hedwigia ciliata (Hedw.) P.Beauv. - 9, 16: on wet acidic rock.

Heterocladiella dimorpha (Brid.) Ignatov \& Fedosov. - 7, 13, 14: on acidic rock, on soil.

Homalothecium lutescens (Hedw.) H. Rob. - 1, 12, 16: on soil, on beech bark.

Homalothecium philipeanum (Spruce) Schimp. - 2, 6: on basic rock, on beech bark.

${ }^{*}$ Homalothecium sericeum (Hedw.) Schimp. - 1, 6, 12: on beech bark.

Hygrohypnum luridum (Hedw.) Jenn. - 7: on wet basic rock.

Hylocomiadelphus triquetrus (Hedw.) Ochyra \& Stebel - 7, 16: on rock.

Hylocomium splendens (Hedw.) Schimp. - 14, 16: on rock.

Hymenoloma crispulum (Hedw.) Ochyra - 5, 7, 12, 14, 15, 16: on acidic rock.

Hypnum cupressiforme Hedw. - 12: on rock.

Hypnum resupinatum Taylor. - 16: on wet rock.

Imbribryum alpinum (Huds. ex With.) N. Pedersen- 5, 16: on rock.

Isothecium alopecuroides (Lam. ex Dubois) Isov. - 5, 13, 14, 15, 16: on wet and dry rocks.

*Kiaeria starkei (F. Weber \& D. Mohr) I. Hagen - 14: on siliceous rock.

Lescuraea incurvata (Hedw.) E. Lawton - 5, 6, 7, 14, 16: on rock, on beech bark.

Lescuraea mutabilis (Brid.) Lindb. ex I.Hagen - 6, 15, 16: on acidic rock, on beech bark.

**Lescuraea patens Lindb. - 13, 14: on basic rock.

Lescuraea plicata (Schleich. ex F.Weber \& D. Mohr) Broth. - 13, 14, 15, 16: on rock.

Lescuraea radicosa (Mitt.) Mönk. - 6, 12, 14: on acidic rock, on beech bark.

**Lescuraea saviana (De Not.) E. Lawton - 1, 6, 14, 15, 16: on basic rock, on beech bark.

**Lescuraea saxicola (Schimp.) Molendo - 6: on rock.

Leucodon sciuroides (Hedw.) Schwägr. - 1, 2, 5, 6, 12, 16: on rock, on beech bark.

**Lewinskya speciosa (Nees) F. Lara, Garilleti \& Goffinet - 13: on beech trunk.

**Lewinskya striata (Hedw.) F. Lara, Garilleti \& Goffinet - 6, 14, 17: on beech and oak bark.

Meesia uliginosa Hedw. - 16: on calcareous rock.

Mnium thomsonii Schimp. - 16: on calcareous rock.

Oligotrichum hercynicum (Hedw.) Lam. \& DC. - 14, 15, 16: on acidic soil. 
**Orthotrichum anomalum Hedw. - 5: on limestone rock.

**Orthotrichum cupulatum Hoffm. ex Brid. - 14: on limestone rock.

Orthotrichum stramineum Hornsch. ex Brid. -6, 13, 14, 15: on beech and willow bark. Oxyrrhynchium schleicheri (R. Hedw.) Röll - 13: on soil.

Palustriella commutate (Hedw.) Ochyra - 14, 15, 16: on wet rock near the stream, on humid soil.

Palustriella decipiens (De Not.) Ochyra - 2, 3, 4, 7, 16: on silicate rock near the stream. Palustriella falcata (Brid.) Hedenäs - 7, 8, 9, 10, 16: on wet rock near the stream.

*Paraleucobryum longifolium (Hedw.) Loeske - 16: on acidic rock.

Philonotis calcarea (Bruch \& Schimp.) Schimp. - 7, 16: on wet rock.

Philonotis fontana (Hedw.) Brid. - 7: wet rock.

Philonotis seriata Mitt. - 7, 8, 9, 10, 14, 15, 16: on wet acidic rock.

Plagiomnium elatum (Bruch \& Schimp.) T. J. Kop. - 16: on wet rock.

Plagiomnium undulatum (Hedw.) T.J.Kop. - 13, 16: on wet rock and soil.

Plagiopus oederianus (Sw.) H.A.Crum\& L.E.Anderson - 14: on calcareous rock.

**Plagiothecium denticulatum (Hedw.) Schimp. - 13, 14, 16: on rock, on rock by the stream.

**Plagiothecium laetum Schimp. - 13, 16: on rock, on rock by the stream.

Plagiothecium nemorale (Mitt.) A. Jaeger - 12, 13, 14: on rock, on rock by the stream.

Pleurozium schreberi (Willd. ex Brid.) Mitt. - 14: on soil.

Pogonatum aloides (Hedw.) P. Beauv. - 16: on acidic soil.

Pogonatum urnigerum (Hedw.) P. Beauv. - 14, 15, 16, 17: on rock, on acidic soil.

Pohlia cruda (Hedw.) Lindb. - 7, 13, 14, 16: on shaded rock, on acidic soil.

*Pohlia melanodon (Brid.) A. J. Shaw - 17: on soil.

Polytrichastrum alpinum (Hedw.) G. L. Sm. - 7, 14, 16: acidic rock, wet rock.

Polytrichum commune Hedw. - 13, 14, 16: on rock.

Polytrichrum formosum Hedw. - 3, 4, 7, 8, 14: on silicate rock.

Polytrichum juniperinum Hedw. - 3, 4, 5, 7, 13, 16, 17: on acidic rock.

Polytrichum piliferum Hedw. - 5, 8, 14, 16: on acidic rock.

Pseudoleskeella nervosa (Brid.) Nyholm. - 1, 2, 3, 4, 5, 13, 14, 15, 16: on beech and oak bark, on calcareous rock.

Pterigynandrum filiforme Hedw. - 1, 2, 5, 6, 13, 16: on beech and oak bark, on rock.

**Ptychostomum capillare (Hedw.) Holyoak \& N. Pedersen - 6, 14, 15: on rock.

*Ptychostomum elegans (Nees) D. Bell \& Holyoak - 13, 16: in humid basic rocks.

**Ptychostomum moravicum (Podp.) Ros \& Mazimpaka - 13, 16: on beech and Platanus bark, on rock.

Ptychostomum pseudotriquetrum (Hedw.) J. R. Spence \& H. P. Ramsay ex Holyoak \& N. Pedersen - 5, 7, 16, 17: on wet basic rocks.

**Ptychostomum pseudotriquetrum var. bimum (Schreb.) Holyoak \& N. Pedersen 13: on wet rock.

Ptychostomum schleicheri (DC.) J. R. Spence ex D. Bell \& Holyoak - 7, 8, 9, 10, 11, 16: on stream and wet rocks.

**Racomitrium aciculare (Hedw.) Brid. -14, 17: on rock, on rock in the stream. 
*Racomitrium affine (F. Weber \& D. Mohr) Lindb. -4, 14, 16: on acidic rocks.

Racomitrium canescens (Hedw.) Brid. -4, 5, 14, 16: on rock, on soil.

**Racomitrium elongatum Ehrh. ex Frisvoll. - 5, 7, 14, 16: on rock.

*Racomitrium lanuginosum (Hedw.) Brid. - 14, 15, 16: on acidic rocks.

*Racomitrium macounii Kindb.subsp. alpinum (E. Lawton) Frisvoll - 14: on acidic rock.

Racomitrium sudeticum (Funck) Bruch \& Schimp. - 14: on acidic rock.

Rhizomnium pseudopunctatum (Bruch \& Schimp.) T. J. Kop. - 14, 16: on wet rock.

Rhizomnium punctatum (Hedw.) T. J. Kop. - 7, 16: on wet rock.

**Rhodobryum roseum (Hedw.) Limpr. - 15: on soil.

*Rhynchostegium murale (Hedw.) Schimp. - 6: on beech bark.

Rhynchostegium riparioides (Hedw.) Cardot. - 16: on wet rock.

**Rhytidiadelphus loreus (Hedw.) Warnst. - 7, 14: on rock.

Rhytidiadelphus squarrosus (Hedw.) Warnst. - 14, 16: on soil.

Rhytidium rugosum (Hedw.) Kindb. - 14, 15: on basic rock.

Saelania glaucescens (Hedw.) Broth. $-5,16$ : on rock crevices.

Sanionia uncinata (Hedw.) Loeske. - 13, 16: on rock, soil, rotten wood.

Schistidium apocarpum (Hedw.) Bruch \& Schimp. - 7, 13, 16: on basic rocks.

**Schistidium crassipilum H. H. Blom. - 3, 4, 13: on rock.

*Schistidium dupretii (Thér.) W. A. Weber - 5, 12, 13, 16: on silicate rocks.

Schistidium papillosum Culm. - 14: on acidic rock.

**Sciuro-hypnum populeum (Hedw.) Ignatov \& Huttunen -14: on rock.

**Sciuro-hypnum reflexum (Starke) Ignatov \& Huttunen - 14, 15, 16: on stone and rock.

**Sciuro-hypnum starkei (Brid.) Ignatov \& Huttunen - 14, 16: on rock.

Streblotrichum convolutum (Hedw.) P. Beauv. - 16: on rock.

**Syntrichia montana Nees. - 14, 16: on limestone rock.

Syntrichia norvegica F. Weber. - 7: on rock.

Syntrichia ruralis (Hedw.) F. Weber \& D. Mohr. - 6, 7, 12, 13, 16: on soil, rocks and tree barks.

**Syntrichia virescens (De Not.) Ochyra - 6: on beech bark.

*Thamnobryum alopecurum (Hedw.) Gangulee - 13: on stones nearby stream.

Timmia austriaca Hedw. - 14, 16: on rubble, on rocks crevices.

**Timmia norvegica J. E. Zetterst. - 13: on limestone rock.

Tortella tortuosa (Hedw.) Limpr. - 5, 6, 7, 8, 9, 14, 15, 16, 17: on basic rocks.

Tortula muralis Hedw. - 2: on concrete.

Tortula subulata Hedw. - 5, 6, 7, 13: on acidic soil.

*Weissia brachycarpa (Nees \& Hornsch.) Jur. - 5: on rock.

**Weissia condensa (Voit) Lindb. - 5: on rock. 